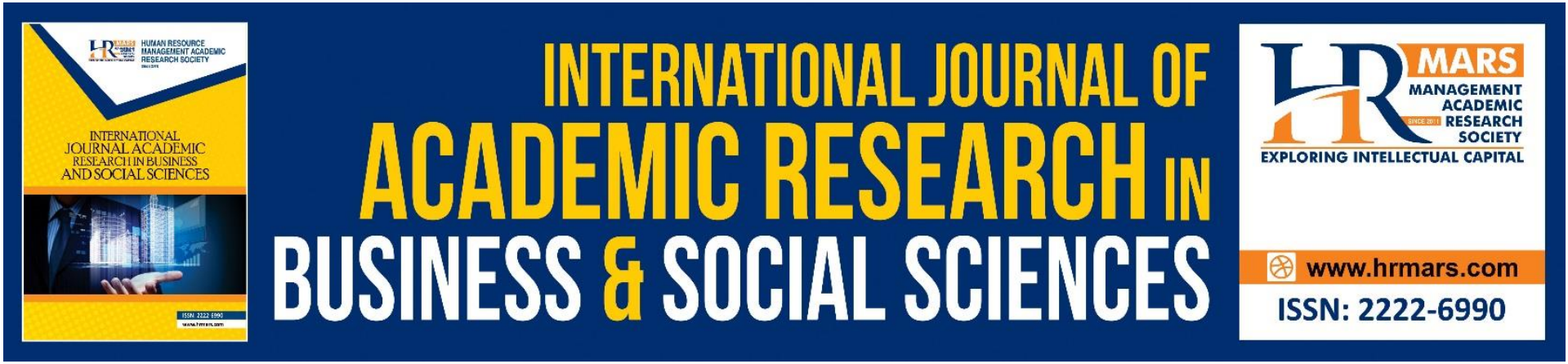

\title{
A Study on The Literary Works of Shaykh Ihsan Dahlan
}

\section{Wan Saleha Wan Sayed, Mohd Hasrul Shuhari, Mohammed Muneer'deen Olodo Al-Shafi'i, Mohd Shaifulbahri Abdullah \& Mohd Manawi Mohd Akib}

To Link this Article: http://dx.doi.org/10.6007/IJARBSS/v10-i11/8208 DOI:10.6007/IJARBSS/v10-i11/8208

Received: 06 September 2020, Revised: 12 October 2020, Accepted: 16 November 2020

Published Online: 25 November 2020

In-Text Citation: (Sayed et al., 2020)

To Cite this Article: Sayed, W. S. W., Shuhari, M. H., Al-Shafi'i, M. M. O., Abdullah, M. S., \& Akib, M. M. M. (2020). A Study on The Literary Works of Shaykh Ihsan Dahlan. International Journal Academic Research in Business and Social Sciences, 10(11), 1289-1297.

\section{Copyright: (c) 2020 The Author(s)}

Published by Human Resource Management Academic Research Society (www.hrmars.com)

This article is published under the Creative Commons Attribution (CC BY 4.0) license. Anyone may reproduce, distribute, translate and create derivative works of this article (for both commercial and non-commercial purposes), subject to full attribution to the original publication and authors. The full terms of this license may be seen at: http://creativecommons.org/licences/by/4.0/legalcode

Vol. 10, No. 11, 2020, Pg. 1289 - 1297

Full Terms \& Conditions of access and use can be found at http://hrmars.com/index.php/pages/detail/publication-ethics 


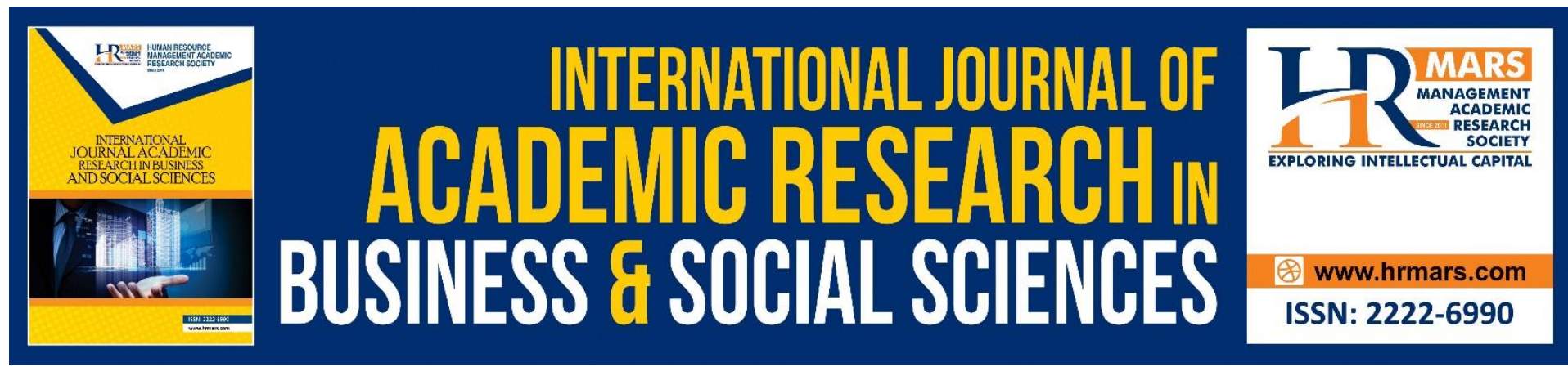

\title{
A Study on The Literary Works of Shaykh Ihsan Dahlan
}

\section{Wan Saleha Wan Sayed, Mohd Hasrul Shuhari, Mohammed Muneer'deen Olodo Al-Shafi'i, Mohd Shaifulbahri Abdullah \& Mohd Manawi Mohd Akib}

Faculty of Islamic Contemporary Studies (FKI), University of Sultan Zainal Abidin (UniSZA), Gong Badak Campus, 21300 Kuala Nerus, Terengganu, Malaysia, The National University of Malaysia (UKM), 43600 UKM, Bangi Selangor, Malaysia.

Email: hasrulshuhari@unisza.edu.my

\begin{abstract}
Shaykh Ihsan Dahlan is a Sufi scholar who is known for his expertise in the discipline of Sufism. $\mathrm{He}$ is a Malay scholar who has produced numerous works in Arabic language. The purpose of this study is to identify the works of Shaykh Ihsan Dahlan. This is to highlight the studies that have been carried out in his works to examine the extent to which his essays have been studied. This study is employs a qualitative method in its approach, using documentation with reference to secondary sources in data collection. The study concludes that among his many well-written works is 'Siraj al-Talibin' through studies that focus on the analysis of his views or thoughts on the science of Sufism. In addition, Shaykh Ihsan Dahlan's thoughts are also seen as more inclined to the scope of Sufism as he incorporates Sufism in commenting on some of the debates in the 'Manahij al-Imdad'. He uses Sufism also in debating non-Sufi disciplines and issues.
\end{abstract}

Keywords: Literary Works, Shaykh Ihsan Dahlan, Sufism, Siraj Al-Talibin, Manahij Al-Imdad.

\section{Introduction}

From an Islamic perspective, Allah s.w.t has honoured the Muslims by making them the best of all nations (Al-Shafi'i et al, 2020). Earlier Muslim scholars have worked hard to produce very important and valuable books, as a valuable legacy for reference and guidance of the entire Muslim community (Adamiyah, 2018). They write their books based on the Quran and the hadith to educate the people. This is important for education because character of education is based on the Quran and Sunnah, which is to embed a certain character and create awareness that teachers and students are able to build their special characters during their life. It also deals with ethics in Islam, referring to the principle of moral (akhlaq) or moral values that became a guidance towards an individual or a group (Shuhari, Ali, Zain, Olodo, Zin \& Omar, 2019).

Building a good character is an important step towards being a 'role model' and being productive in playing a good role (Al-Shafi'i et al, 2019). This is the trust and responsibility that 
scholars and teachers should pay attention to. Trust and responsibility which refer to the ethical character of man that must be practiced daily (Shuhari et al, 2019). It is also about integrity. From the Islamic perspective, integrity can be attributed directly, and in parallel, to the attributes of trust, honesty, faith, strong belief, powerful character and noble manners (Shuhari et al, 2019). One of the conditions in the Sufism is that one must adhere to the faith of the Sunnah wal Jama'ah. Among the Sunnah wal Jama'ah is the belief that God is different from His creatures. All scholars unanimously agree that Allah s.w.t is totally different from all creatures (al-hawadith) in every aspect (Basri, Shuhari \& Zin, 2019).

Writing about Sufism is very important. This is because it focuses on the element of morality which is one of the three pillars of religion in Islam. Sufism emphasizes sincere relationships among Muslims. Human beings are able to use language to speak, write and communicate and establish relationships with other people in the world (Zakaria et al, 2020). By using clear and polite language, it will lead to unity in society. The result of their scholarly missions is unlimited; it involves many fields of knowledge. In this regard, this study is focused on highlighting studies conducted on the writings of Shaykh Ihsan Dahlan to examine the extent to which his works have been studied.

\section{Biography of Shaykh Ihsan Dahlan}

Shaykh Ihsan Dahlan is one of the Malay leading scholars who have produced works in disciplines such as Islamic Sufism, astronomy and jurisprudence. The credibility of Shaykh Ihsan Dahlan quite obvious, and this is prevalent in his book on Sufism titled Siraj al-Talibin. This book is being referred and reviewed both at home and abroad (Adamiyah, 2018; Moissidou, 2013). This shows the widespread influence of Shaykh Ihsan Dahlan's work. His writings have been impactful on not just the Malay community but also the global community. Apart from Siraj al-Talibin, he has produced other works, such as Tasrih al-'Ibarat where he discusses astronomy, Manahij al-Imdad where he discusses the science of Sufism, and Irshad al-Ikhwan li Bayani Shurb al-Qahwah wa al-Dukhan where he discusses the law on smoking and drinking coffee (Ni'am, 2015).

Shaykh Ihsan Dahlan is a Sufi scholar. His full name is Ihsan Muhammad bin Dahlan bin Saleh Jampes. He is well known for Kiai Ihsan Jampes. His childhood name was Bakri. He was born in 1901CE in Kampung Putih, Gampengrejo, Kediri, East Java to a well-respected family. His father's family was of sultanate descent from Kuningan district. His father is Kiai Dahlan from Bogor, West Java. Not only that, his father also had a lineage with one of the Wali Songo in Cirebon, Sunan Gunung Jati or Sharif Hidayatullah. His grandfather, Kiai Saleh, was a traveler who traveled all the way to East Java in pursuit of knowledge and was a pious man in religious sciences. The wife of Kiai Saleh was Isti'anah, the daughter of Kiai Mesir. His mother was the daughter of Kiai Soleh who came from Banjarmelati, Kediri named Artimah. However, the marriage between the parents of Shaykh Ihsan Dahlan did not last long; they were divorced (Adamiyah, 2018). He pointed out that Shaykh Ihsan Dahlan was indeed of an ancient lineage clearly revealed through the well-respected family lineage from both his mother and father sides. They were of pious scholars descendants.

After his mother and father divorced, Shaykh Ihsan Dahlan was raised by his grandmother, Isti'anah, along with his younger brother, Dasuki. He had previously received religious guidance from his parents and grandparents and then began to seek religious 
knowledge in various pesantren (traditional) schools (Sa'adah, 2015). He started his first studies at Pesantren Bendo Pare Kediri under the care of his uncle, Kiai Khozin. After that, he moved from one pesantren school to another, including Pesantren Jamseran Solo, Pesantren KH. Ahmad Dahlan Darat Semarang, Pondok Pesantren Mangkang Semarang, Pondok Pesantren Punduh Magelang, Pondok Pesantren Gondanglegi Nganjuk and Pondok Pesantren Bangkalan Madura (Wasid, 2016).

Later, Shaykh Ihsan Dahlan had to leave all pesantren schools, upon the request of his father, for Pesantren Jampes School (his father's pesantren school), to teach the students therein. In 1926CE, Shaykh Ihsan Dahlan performed his pilgrimage, after which his childhood name, Bakri, was changed to Ihsan. His new name was chosen in the hope that he could change his life for the better and become a true Muhsin (good people). In 1928CE, his father passed away, and the leadership of the Pesantren Jampes was handed to his uncle, KH. Kholil, who was also know as Muharrar. In 1932CE, at the age of 31, the leadership of Pesantren Jampes was handed over to Shaykh Ihsan Dahlan by his uncle, KH. Kholil. Shaykh Ihsan Dahlan has several failed marriages, but his last marriage to a woman named Surati lasted and produced eight children. On Monday, 25 Zulhijjah 1371AH (September 1952CE), he joined his ancestors, at Jampes, Kediri (Masruri, Nordin \& Mohammad, 2019).

\section{The Works of Shaykh Ihsan Dahlan}

Throughout his life, Shaykh Ihsan Dahlan has produced numerous works in various fields of knowledge. This includes writings in sufism, astronomy and religios sciences. Following are some of his works.

\section{Tasrih al-'Ibarat}

This 48 pages book (Sa'adah, 2015) was published in 1929CE, and it discusses astronomy. Tasrih al-'Ibarat is a description (sharh) to the book of Natijah al-Miqat of Shaykh Ihsan Dahlan's teacher, KH. Ahmad Dahlan Semarang, a specialist in the field of astronomy (Adamiyah, 2018). His father, Kiai Dahlan Soleh, the founder of Pondok Pesantren Jampes, was also an expert in the field of astronomy, and indirectly the writing of this book shows that Shaykh Ihsan Dahlan plays a role in preserving the scientific heritage in the Pesantren Jampes (Wasid, 2014). As his father specialized in astronomy, so does Shaykh Ihsan Dahlan himself who is well versed in this field. Through his expertise, he has produced his own prayer timetable at the Pondok Pesantren Jampes and the early setting of the Hijra months (Sa'adah, 2015). In examining the studies of this book, no studies have been conducted on Tasrih al'Ibarat.

\section{Siraj al-Talibin}

Siraj al-Talibin is a book on Sufism. It was written in Arabic and is a description (sharh) to the book Minhaj al- 'Abidin (Ni'am, 2015) of the leading Sufi scholar, Imam al-Ghazali. The writing of this book has proven the greatness of Shaykh Ihsan Dahlan, as he wrote the book in just eight months (Wasid, 2014). That is a two volumes book of over a thousand pages, while the original book, Minhaj al-'Abidin, is only 93 pages (Sa'adah, 2015). This book is the most famous of his writings; it has been studied by graduate students at al-Azhar University, Egypt. The fame of this book is not only in the Malay world, it is as well famous to the global community, as it is studied in Turkey, Egypt and the United States (Adamiyah, 2018). 
In addition, the greatness of this work is expressed through the many compliments and accolades that have been uttered by Muslim scholars. One of them is the praise of a founder and educator at the Pondok Pesantren Tebuireng Jombang, Kiai Haji Hasyim Asy'ari. He considers Siraj al-Talibin a great syllabus book; its contents are rich in benefits because it was produced by Shaykh Ihsan Dahlan who is quite pious and discerning in the field he studied. Kiai Haji Abd al-Karim Lirboyo Kediri, Kiai Haji Muhammad Ma'ruf Kedunglao Kediri and Kiai Haji Muhammad Khazin Salih Bendo Pare Kediri were also among scholars who have acknowledged the authenticity and high regard of Siraj al-Talibin (Wasid, 2014). The masterpiece of this work became more apparent when it was published by Musthafa al-Babi al-Halabi, a leading publisher in Egypt (Hidayat, 2015). Siraj al-Talibin is his greatest work as it is through it that he has become well known (Arifin \& Asif, 2015). Through this work, he was also known as a Sufi scholar. In line with the research conducted on Siraj al-Talibin, we present some studies that have been conducted on this book as follow:

First is a doctoral dissertation of Wasid, titled Pemikiran Tasawuf Kiai Ihsan Jampes Kediri perspektif sosiologi pengetahuan (Tasawuf thoughts according to Kiai Ihsan Jampes based on the knowledge of sociology). This study is from UIN Sunan Ampel Postgraduate Program in 2014. The discussion of this study focuses on understanding the concept of Sufism according to Shaykh Ihsan Dahlan. This study draws on Shaykh Ihsan Dahlan's thoughts on Sufism through his Siraj al-Talibin and Manahij al-Imdad (Arifin \& Asif, 2015).

Second is an article by Moch. Arifin and Moh. Asif, titled Penafsiran al-Qur'an Kh. Ihsan Jampes; studi intertekstualitas dalam kitab Siraj al-Talibin (Interpretation of the Qur'an according to Kh. Ihsan Jampes; the study of intertextuality in the book of Siraj al-Talibin). This article was published in al-Itqan Journal, and quotes Siraj al-Talibin which focuses on the interpretation of Quranic verses by Shaykh Ihsan Dahlan. More specifically, this study focuses on analyzing the sources referred to by Shaykh Ihsan Dahlan in interpreting the Quranic verses presented in both volumes of Siraj al-Talibin (Arifin \& Asif, 2015).

Third is a postgraduate study by Rofiatul Adamiyah, titled Interpretasi sufistik hadis tentang ru'yatullah fi al-akhirah dalam pandangan ulama Nusantara: studi kitab Siraj al-Talibin karya Kiai Ihsan Jampes (The Sufistic Interpretation of the hadith about ru'yatullah fi alakhirah in the view of the scholars of the Archipelago: a study of the Siraj al-Talibin written by Kiai Ihsan Jampes). This study is based on Siraj al-Talibin, focusing on the debate on ru'yatullah fi al-akhirah, i.e seeing Allah in the last day. Among the questions raised in this study are debates about hadith and the methodology applied in understanding it according to the Sufis. In addition, this study also describes the methodology used in Siraj al-Talibin (Adamiyah, 2018).

\section{Manahij al-Imdad}

Manahij al-Imdad is a commentary on Irshad al-'Ibad ila sabil al-Rashad of Shaykh Zayn al-Din bin 'Abd al-'Aziz al-Malibari (Hidayat, 2015). The book addresses debates on faith, jurisprudence, and Sufism. The book has revealed the authorship and expertise of Shaykh Ihsan Dahlan as he has been able to conduct in-depth analysis and reviews of Irshad al-'Ibad. It was produced in two volumes of over a thousand pages, although Irshad al-'Ibad itself is only a hundred and eighteen pages. The book was written by Shaykh Ihsan Dahlan in 1940CE in sound traditional Arabic language. Shaykh Ihsan Dahlan is more likely to have commented 
on Irshad al-'Ibad using Sufism approach in each of his reviews, both in describing debate on faith and jurisprudence. This clearly indicates that Shaykh Ihsan Dahlan's views are more inclined towards Sufism (Wasid, 2014).

Although the book was written in 1940CE, its publication was delayed till after Shaykh Ihsan Dahlan's death in 2005CE. This was due to the situation, a poor social political position coined with the war between 1942CE and 1950CE. In fact, the attempt to publish the book was made at a printing company in Cairo, but it was not successful until the death of Shaykh Ihsan Dahlan in 1952CE. Later, his family continued to try to find the book, including trying to obtain a manuscript in Cairo, but the attempt failed. However, the manuscript was eventually found in a copy edition by one of the students of Shaykh Ihsan Dahlan at Semarang. Manahij al-Imdad was later published in 2005CE under the publication of his large family (Wasid, 2014).

A review on Manahij al-Imdad reveals that only one study has been conducted on this work, a doctoral dissertation of Wasid, mentioned earlier. The purpose of the dissertation was to find out the concept of Sufism according to Shaykh Ihsan Dahlan, to study the aspects that influenced Shaykh Ihsan Dahlan in understanding the concept of Sufism and to know the position of Shaykh Ihsan Dahlan in the world of study and Islamic world. In summary, the main focus of this study is to focus on the contribution of Shaykh Ihsan Dahlan's thought in Siraj alTalibin and Manahij al-Imdad (Wasid, 2014).

\section{Irshad al-Ikhwan li Bayani Shurb al-Qahwah wa al-Dukhan}

This book dealing with drinking coffee and smoking from an Islamic law perspective, it was originally written in Arabic language. It is a four chapter book, and its title illustrates that it is writing themed on jurisprudence, especially with regard to smoking and drinking coffee (Wasid, 2016). More clearly, the questions raised in this book are the differences in views on the legality of coffee and smoking among scholars. Shaykh Ihsan Dahlan himself in the debate on smoking through this book is seen as more inclined to the view that it is not haram (illegal) as long as there is no perceived harm to human body (Sa'adah, 2015). This book has been translated into Indonesian language, and was published in 2009CE, by LKIS Yogyakarta. It was reprinted in 2012CE AD (Wasid, 2016).

Based on the previous studies, Irshad al-Ikhwan is among the works of Shaykh Ihsan Dahlan which has been thoroughly researched. First among these researches is Kontroversi hukum rokok dalam kitab Irshad al-Ikhwan karya Syekh Ihsan Muhammad Dahlan (Controversy over the law of cigarette in Irshad al-Ikhwan of Shaykh Ihsan Muhammad Dahlan) of R. Aris Hidayat. This article is published in International Journal Ihya 'Ulum al-Din vol. 17 no. 2 in 2015CE. Among the arguments presented in this paper are a brief summary of Irshad al-Ikhwan's work and his views on cigarettes according to Shaykh Ihsan Dahlan. This article also focuses on smoking laws, which include makruh (condemned), haram (prohibited) and mubah (permissible) by Shaykh Ihsan Dahlan and other scholars. Generally, the main focus of this study was on the debate on smoking and particularly the view of Shaykh Ihsan Dahlan through his Irshad al-Ikhwan (Hidayat, 2015).

Second is Merawat keberagaman di balik perdebatan kopi dan rokok: kajian atas kitab Irshad al-Ikhwan li Bayani Ahkami Shurb al-Qahwah wa al-Dukhan K.H. Ihsan Jampes Kediri 
(Treating diversity behind coffee and cigarette debate: a study on Irshad al-Ikhwan li Bayani Ahkami Shurb al-Qahwah wa al-Dukhan of K.H. Ihsan Jampes Kediri) of Syamsun Ni'am. This article was published in Jurnal Lektur Keagamaan (Journal of religious lectures), vol. 13 no. 2 in 2015. The paper focuses on issues related to coffee drinking and smoking, looking at the views of Shaykh Ihsan Dahlan in his Irshad al-Ikhwan li Bayani Ahkami Shurb al-Qahwah wa al-Dukhan. It also explains it from the perspective of Sufism in dealing with the existence of various views of the scholars on issues related to coffee drinking and smoking ( $\left.\mathrm{Ni}^{\prime} \mathrm{am}, 2015\right)$.

Third is Ngudud dan ngipok menurut Syaikh Ihsan Muhammad Dahlan al-Jampesi Kediri (Cigarettes and coffee according to Shaykh Ihsan Muhammad Dahlan al-Jampesi Kediri), a postgraduate study written by Arifatus Saadah. This study was conducted in 2015CE at the Fakulti Adab dan Humaniora UIN Sunan Ampel. It was conducted on Irshad al-Ikhwan li Bayani Ahkam Shurb al-Qahwah wa al-Dukhan with the main aim of focusing on the study of Shaykh Ihsan Dahlan's views on smoking and drinking coffee. The study includes a copy of the poem contained in the book which was later translated into Indonesian language. This study includes the discussion of cigarettes and coffee from health and medical perspectives (Sa'adah, 2015).

And, last is Knowing coffee and smoking laws through literary texts in Irshadu alIkhwanu li Bayani Shurbi al-Qahwati wa ad-Dhukhani by Sheikh Ihsan ibn Dahlan Jampes of Devina Gary Oktiana and Maman Lesmana. The article was published in Journal of humanities and social science, vol. 22, 2017. The paper focuses on the methodology, language style and textual content of Irshad al-Ikhwan's text. It also discusses to what extent the debate has affected Muslims on the issue of drinking coffee and smoking cigarettes. Generally, the paper focuses on analysing the structure and textual content of the book (Oktiana \& Lesmana, 2017).

According to the sources cited, only four works of Shaykh Ihsan Dahlan have been found. All four of these works are undoubtedly his work. However, there is also a history claiming that there was another work authored by Shaykh Ihsan Dahlan titled Nur al-Ihsan fi Tafsir al-Qur'an. The work is claimed to discuss the discipline of tafsir (interpretation of alQur'an). It is found in the book of al-'Aqd al-Farid min Jawahir al-Asanid, a book ascribed to Shaykh Muhammad 'Isa al-Fadani al-Makki (Wasid, 2016). However, there is still no solid evidence to determine whether the work was the work of Shaykh Ihsan Dahlan or vice versa. This is because the printing of the work has not been found at the time of concluding this study.

\section{Conclusion}

In conclusion, Shaykh Ihsan Dahlan has produced four major notable writings, and these works are globally acknowledged. His Siraj al-Talibin brought him to fame; it depicts him as a Sufi scholar. The book is also one of his most widely researched works by scholars, especially in the studying and analysing his Sufi aspects. In addition, Irshad al-Ikhwan li Bayani Shurb alQahwah wa al-Dukhan was also extensively researched. It expresses his views on smoking and drinking coffee, as well as on the methodological aspects of writing the book itself. However, no studies have been found on Tasrih al-'Ibarat. Based on his works, it can be concluded that his thinking tends to the field of Sufism. This is because two of his four works, namely, Siraj 
al-Talibin and Manahij al-Imdad, discuss Sufism. In Manahij al-Imdad, even though he was commenting on jurisprudence, he included elements of Sufism in his description.

\section{Acknowledgement}

Special appreciation is owed to Sultan Zainal Abidin University (UniSZA), for supporting this research.

\section{Corresponding Author}

Mohd Hasrul Shuhari

Centre for Usuluddin Studies, Faculty of Islamic Contemporary Studies (FKI), University of Sultan Zainal Abidin (UniSZA), Gong Badak Campus, 21300 Kuala Nerus, Terengganu, Malaysia.

Email: hasrulshuhari@unisza.edu.my

\section{References}

Adamiyah, R. (2018). Interpretasi sufistik hadis tentang ru'yatullah fi al- akhirah dalam pandangan ulama nusantara (studi kitab Siraj al-Talibin karya Kiai Ihsan Jampes). M.S. thesis, Program Jurusan Ilmu Hadis, Universitas Islam Negeri Sunan Ampel.

Arifin, M., and Asif, M. (2015). Penafsiran al-Qur'an Kh. Ihsan Jampes; studi intertekstualitas dalam kitab Siraj al-Talibin, Jurnal al-Itqan, Vol. 1, No. 2, pp. 63-87.

Basri, H. M. N., Shuhari, M. H., and Zin, E. W. E. I. (2019). Mukhalafatuhu li al-hawadith according to commentators of Matn Jawharah al-Tawhid (Mukhalafatuhu li al-hawadith menurut perspektif Shurrah Matan Jawharah al-Tawhid), Jurnal Akidah \& Pemikiran Islam (AFKAR), [S.I.], Vol. 21, No. 1, pp. 53-84.

Hidayat, R. A. (2015). Kontroversi hukum rokok dalam kitab Irsyad al-Ikhwan karya Syekh Ihsan Muhammad Dahlan, International Journal Ihya' 'Ulum al-Din, Vol. 17, No. 2, pp. 189-208.

Masruri, M., Nordin, S. R. A., and Mohammad, C. A. (2019). Kaedah penulisan hadis Shaykh Ihsan Muhammad Dahlan al-Jampasi dalam kitab Siraj al-Talibin (methods of writing the hadith of Shaykh Ihsan Muhammad Dahlan al-Jampasi in the book of Siraj al-Talibin), Journal of Advanced Research in Social and Behavioural Sciences, Vol. 17, No. 1, pp. $32-$ 40.

Moissidou, E. (2013). Practices of primary education principals in Greece: Consensus and enforcement. Multilingual Academic Journal of Education and Social Sciences, 1(2), 123-137.

Nafi, N. M., Mokhtar, W. K. A. W., \& Mustaffami, M. (2019). The Holy Quran Memorization in Globalization Era. International Journal Of Academic Research In Business And Social Sciences, 9(11).

Ni'am, S. (2015). Merawat keberagamaan di balik perdebatan kopi dan rokok (kajian atas kitab Irshad al-Ikhwan li Bayani Ahkami Shurb al-Qahwah wa al-Dukhan, Jurnal Lektur Keagamaan, Vol. 13, No. 2, pp. 533-554.

Oktiana, D. G., and Lesmana, M. (2017). Knowing coffee and smoking laws through literary texts in Irshadu al-Ikhwanu li Bayani Shurbi al-Qahwati wa ad-Dhukhani by Sheikh Ihsan ibn Dahlan Jampes, IOSR Journal of Humanities and Social Science, Vol. 22 No. 9, pp. 4957. 
Hamid, N. C., \& Mokhtar, W. K. A. W. (2019). The Comprehensive Aspect in Islam from Quran and Hadith Perspective. International Journal Of Academic Research In Business And Social Sciences, 9(11).

Sa'adah, A. (2015). Ngudud dan ngipok menurut Syaikh Ihsan Muhammad Dahlan al-Jampesi Kediri. M.S. thesis, Jurusan Sejarah dan Kebudayaan Islam (SKI), Universitas Islam Negeri Sunan Ampel.

Shuhari, M. H., Ali, M. S., Md. Zain, A. D., Olodo Al-Shafi'i, M. M., Zin, M. S. A., and Omar, S. H. (2019). The ethical character of Sultan Muhammad al-Fatih in leadership, Journal of Legal, Ethical and Regulatory Issues, 22(S1), pp. 1-6.

Shuhari, M. H., Engku Wok Zin, E. I., Olodo Al-Shafi'i, M. M., Musa, R., Mohamad Zin, S. A., and Syed Omar, S. H. (2019). An ethical aspect of character building: ibn Sina's perspective, Journal of Legal, Ethical and Regulatory Issues, 22(S1), pp. 1-5.

Shuhari, M. H., Hamat, M. F., Basri, H. M. N., Khairuldin, W. M. K. F., Wahab, M. R., Engku Alwi, E. A. Z., and Mamat, A. (2019). Concept of al-amanah (trustworthiness) and almas'uliyyah (responsibility) for human's character from ethical Islamic perspective, Journal of Legal, Ethical and Regulatory Issues, 22(S1), pp. 1-5.

Shuhari, M. H., Hamat, M. F., Al-Shafi'i, O. M. M., Jusoh, W. H., Zin, M. S. A., and Wahab, M. R. (2019). The concept of integrity for muslim's character based on al-Ghazali's ethical perspective, Journal of Legal, Ethical and Regulatory Issues, 22(S1), pp. 1-5.

Wasid. (2014). Pemikiran tasawuf Kiai Ihsan Jampes Kediri perspektif sosiologi pengetahuan. Doctoral Dissertation, Program Studi IImu Ke-Islaman, Universitas Islam Negeri Sunan Ampel.

Wasid. (2016). Tasawuf nusantara Kiai Ihsan Jampes, Surabaya: Pustaka Idea. 